\title{
Professor Brunello Wüthrich zum 65. Geburtstag
}

\author{
Am 21. Juni 2003 feierte Prof. Dr. med. Brunello Wüthrich seinen \\ 65. Geburtstag. Die Deutsche Gesellschaft für Allergologie und \\ klinische Immunologie übermittelt ihrem langjährigen \\ Mitglied (seit 1969) und Ehrenmitglied (seit 2002) hierzu alle \\ guten Wünsche.
}

C ast zeitgleich mit seinem 65. Geburtstag hat Prof. Wüthrich am 19. Juni auch seine klinische Tätigkeit beendet, davon allein 28 Jahre als Leitender Arzt der Allergiestation der Dermatologischen Universitätsklinik Zürich. Herr Wüthrich wurde im Tessin, in Soregno bei Lugano, geboren. Seit 1965 ist er an der Dermatologischen Universitätsklinik Zürich tätig, seit 1981 Titularprofessor, seit 1985 Extraordinarius.

Mit seinem Namen ist eine Fülle von Studien zu zahlreichen allergologischen Themen verbunden und es ist sicherlich nicht übertrieben, ihn zu den herausragenden klinischen Allergologen der zweiten Hälfte des 20. Jahrhunderts zu zählen. Herr Wüthrich hat neben seiner intensiven klinischen Tätigkeit eine Fülle weiterer Aufgaben übernommen, mit dem Höhepunkt der Präsidentschaft und Leitung der Jahrestagung der Europäischen Akademie für Allergologie und klinische Immunologie 1991 in Zürich.

Herr Wüthrich ist der DGAI seit Jahrzehnten eng verbunden. 1975 wurde er für seine Habilitationsschrift: „Zur Immunpathologie der Neuroder-

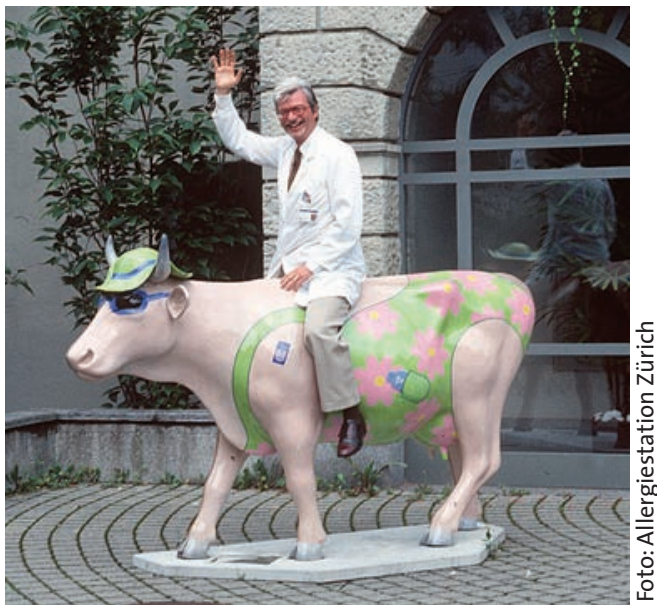

\section{Sattelfest in nahezu allen allergologischen} Fragestellungen: Prof. Dr. Brunello Wüthrich

mitis constitutionalis" mit dem KarlHansen-Gedächtnispreis der DGAI ausgezeichnet. Über Jahrzehnte hat er Kontakte zu zahlreichen Mitgliedern der DGAI gehalten.

Ad multos annos!

Prof. Dr. Gerhard Schultze-Werninghaus, Bochum

\section{Klosterfrau Award for Childhood Asthma 2003}

The „Klosterfrau Research-Award for Childhood Asthma" has been installed as an annual prize. It will be awarded to researchers in basic science, pneumology and pediatrics whose work is orientated to the better understanding of childhood asthma.

The prize is endowed with 40.000 SFR (Swiss Francs) and will be given to one person or team. 10.000 SFR of this sum are at the individual disposal of the prize winner (winning team), whereas 30.000 SFR have to be spent for further research of the winner or his team.

\section{Guidelines:}

1. The applicant must be under the age of 40 years.

2. Each application must be by a single applicant.

3. The work must be from the past 2 years.

4. The work may be clinical or basic research in asthma, by a researcher whose major clinical training and work has been in pediatrics.
5. Majority of the research work should have been performed by the applicant.

6. Application should contain a short statement of the head of the research group that he/she (the group) supports the application.

7. The applicant must submit a short curriculum vitae and a list of his/her publications.

8. The applicant must submit a summary of his/her work, with an indication of its clinical relevance to childhood asthma and which questions arising from the work need to be answered in the future.

9. Reviews of the literature will not be accepted.

10. Papers or PhD thesis should be presented as a supplement to the application.

11. Universal application form should be used. It must contain: — Title and full address

- Manuscript(s)

- A summary of the work

_ Curriculum vitae and list of publications
_Explanations (by the Applicant and the head of the research group that the applicant has performed majority of the research work).

Selection of the award recipient(s) will be made of an international scientific board, made up of six internationally recognized senior scientists. Please send your application ( 6 copies) by November 1st, 2003 at the latest to the Chairman of the International Scientific Board.

\section{Prof. Dr. D. Reinhardt}

Dr. v. Haunersches Kinderspital

University of Munich (LMU)

- Klosterfrau Preis -

Lindwurmstr. 4

80337 München

Phone: (++ 49-89) 51 60-77 01

Fax: (++ 49-89) 51 60-77 02

e-mail: Dietrich.Reinhardt@

kk-i.med.uni-muenchen.de

Internet: www.med.uni-muenchen.de/gpp 